\title{
EFFECT OF BEET SUGAR (Beta Vulgaris L) IN LOWERING HIGH BLOOD PRESSURE AMONG THE ELDERLY
}

\author{
Kuntari Astriana, Devillya Puspita Dewi \\ Department of Nutrition Science, Faculty of Health Sciences, \\ Universitas Respati Yogyakarta
}

\begin{abstract}
Background: High blood pressure is a risk factor for cardiovascular disease. Beets have various vitamins, minerals, fiber, folate, mangan, and nitrate. Nitrate in the body is converted into biologically active nitrite and nitric oxide. Nitric oxide can help relax and dilate blood vessels. This study aimed to determine the effect of beet sugar (Beta Vulgaris. $L$ ) in lowering high blood pressure among the elderly.

Subjects and Method: This was a quasi-experiment study one group before after with no control design carried out at Gunungan Integrated Health Post Elderly, Pleret, Yogyakarta. A sample of 22 elderly aged $\geq 56$ years old was selected for this study. The dependent variable was blood pressure. The independent variable was consumption of $200 \mathrm{ml}$ of beet juice for 6 days in a row. Blood pressure was measured by sphygmomanometer. The data were analyzed by paired t-test.

Results: Systolic blood pressure after intervention (Mean=155.00; $\mathrm{SD}=21.46)$ was lower than before intervention (Mean $=170.86 ; \mathrm{SD}=25.67)$ and it was statistically significant $(\mathrm{p}<0.001)$. Diastolic blood pressure after intervention (Mean= 92.54; $\mathrm{SD}=$ 12.14) was lower than before intervention (Mean $=97.54 ; \mathrm{SD}=12.88)$ and it was statistically significant $(\mathrm{p}=0.014)$. This reduction, however, was not large enough to reach the minimum clinically meaningful blood pressure level, i.e. $140 \mathrm{mmHg}$ for systolic blood pressure and $90 \mathrm{mmHg}$ for diastolic blood pressure.

Conclusion: Beet sugar decreases both systolic and diastolic blood pressures among the elderly, but this reduction is not large enough to reach the minimum recommended blood pressure level. Further studies are recommended to address this research question using randomized control trial (RCT) to provide stronger evidence.
\end{abstract}

Keywords: beet sugar, systolic, diastolic, blood pressure, hypertension, elderly.

Correspondence:

Kuntari Astriana. Department of Nutrition Science, Faculty of Health Sciences, Universitas Respati Yogyakarta. Email: kuntariastria@gmail.com. Mobile: 085713179144.

The $6^{\text {th }}$ International Conference on Public Health Best Western Premier Hotel, Solo, Indonesia, October 23-24, 2019 | 360 https://doi.org/10.26911/the6thicph.05.25 